\title{
Effects of Botanical Extracts on Fungal Load of Sesame (SesamumindicumL.) Seeds
}

\author{
Anjorin, Samuel Toba ${ }^{1}$, Salako, Ezekiel Adebayo ${ }^{2}$, Oluchi Nwogbo ${ }^{3}$ \\ ${ }^{1,2,3}$ Department of Crop Science, Faculty of Agriculture, University of Abuja, PMB 117, Abuja
}

\begin{abstract}
This study assessed the mycoflora load on pesticidal botanical materials and on infected sesame (Sesamumindicum L.)Seeds treated with antifungal botanicals in the laboratory using Agardilutionmethod. Six botanical materials were screened and baobab (Adansoniadigitata), hot pepper (Capsicum annum) and ordeal tree (Erythrophleumsuaveolens) leaf extracts had no fungal load. The antifungal activity of the extract of these botanicals (10\% and $100 \%$ conc.) was evaluated against the isolated fungi from infected sesame seeds.The pathogenic fungi isolated from the sesame seeds were Aspergillusniger, A. flavus, Mucor spp., Fusarium spp., Alternaria spp. and Penicilliumspp. Baobab and ordeal leaf extracts (10\% and 100\% conc.) had maximal antifungal activity (p<0.05) on all the six assessed seed-borne fungi. Hot pepper extracts (10\% and 100\%) inhibited only the mycelial growth of A. flavus and Alternaria spp. This study confirmed the variation in the fungal load of some Nigerian plant materials and indicated the effectiveness of baobab (AdansoniadigitataL.) leaves, pepper (Capsicum annum) fruit and ordeal tree (Erythrophleumsuaveolens) leaf extracts as antifungal agents on seed-borne fungi of sesame. The effect of these extracts on germinabilityof the seeds and seedling vigour deserve further investigation.
\end{abstract}

Keywords: fungal load, sesame seeds, ginger extract, hot pepper extract, baobab leaf extract, ordeal tree extract

\section{Introduction}

Sesame (SesamumindicumL.) popularly known as beniseeds in English, ridi in Hausa or gorigo in Ebira is considered to be the oldest oil seed crop known to humanity. One of the constraints of sesame seed is the adverse effect of seedborne infection which often results in poor quality seed and oil as well as transmission of seed-borne pathogens to mature plants.

Seed-borne fungi of sesame seed have been reported to include Alternariabrassicola, A. redicina, A. alba, A. flavus, A. niger, A. viridus, Cephalosporiumspp., Curvularia, Drechsler spp., Fusariumand Penicillium spp. in Pakistan [1]. Also in Sudan [2] Nasireedeenet al., reported Macrophominaphaseolina, Aspergillusniger, A. flavus, Alternariaspp., Fusariumspp., Curvulariaspp. and Dredoslerarostrata to be found in sesame seeds.

The use of botanicals in the control of plants pathogens is an alternative technique to the conventional handling with synthetic fungicides which causes various problems such as toxicity to users [3] Whalen et al.; impairment of beneficial organism and resistance to the active ingredients of some synthetic fungicide in response to selection pressure due to high dose and continuous application, which have all led to great economic losses [4]-[5]. An economical and efficient alternative for disease control is the use of natural products derived from plants (secondary metabolites) [6] Wilson et $a l$., since it is environment-friendly and their residues are easily degradable.

The potential use of plant extracts to control plant pathogen has been reported in different laboratory [7]-[9], green house and field studies [10] (Hernandez et al. 2010), botanicals offer a more economical and efficient alternative for disease control.
[11] Al-samarrai et al., in their study evaluated botanicals prepared from neem, chilli, lemon grass and ginger among others and showed that neem and chilli were more effective at inhibiting the test fungi than ginger and lemon grass. Aspergillus spp. mycelia grown for $96 \mathrm{~h}$ in culture media containing $50 \%$ neem leaf and seed extracts was inhibited by 90 and 65\%, respectively [12] Razzaghi-Abyaneh et al. Also non-sterilized phyto extracts of Allium sativum and Sapindus trifoliate were inhibitory to Fusariummoniliforme the incitant of wilt of sugarcane [13]. Allium sativum was also reported to inhibit the development of fungal mycelium of Macrophominaphaseolina which is known to affect groundnut [14].Due to problems caused by seed-borne fungi to the crop, which include porr establishment and productivity, the effectiveness of some botanicals in controlling the fungal load on sesame seeds when investigated. It specifically investigated the fungi load in ordeal tree stem bark and leaves, garlic, ginger, hot pepper, baobab marketed in Gwagwalada-Abuja, Nigeria and to quantify and identify fungi load on the infected sesame seeds treated with hot pepper, baobab and ordeal tree leaves.

\section{Materials and Methods}

Collection of botanical materials and sesame seeds

Dry ordeal tree stem bark and leave, hot pepper fruits, garlic bulbs, ginger rhizomes, baobab leaf powder, and sesame seeds were purchased from Gwagwalada, Abuja market and kept safe in a polythene bags and shade dried on the laboratory benches for 3 weeks.

The sample of ordeal tree stem bark and leaves, ginger rhizomes, garlic bulbs, hot pepper fruits and baobab were all ground into powder with a pestle and mortar in the laboratory.

Preparation of the sesame seeds

Two grams of sesame seeds were surface sterilized for 2 (mins) in $80 \%$ ethanol and rinsed twice in sterile distilled 


\section{International Journal of Science and Research (IJSR) \\ ISSN (Online): 2319-7064}

Index Copernicus Value (2013): 6.14 | Impact Factor (2014): 5.611

water and was later grounded into fine powder with a pestle and mortar in the laboratory, the essence of sterilization is to kill microorganisms.

\section{Determination of fungal load on botanical materials and sesame seeds}

One gram of each hot pepper, garlic, ginger, baobab, ordeal tree stem bark and leaf extract and sesame seeds sample that were ground into fine powder was added to $9 \mathrm{ml}$ portion of sterile water in a test- tube and was shaken very well. Four fold serial dilutions $10^{-1}, 10^{-2}, 10^{-3}, 10^{-4}$, were then prepared. $19.5 \mathrm{~g}$ of Potato Dextrose Agar (PDA) was introduced into a conical flask containing $500 \mathrm{ml}$ of distilled water and autoclaved at $121^{\circ} \mathrm{C}$ for 15 mins. To this, $13 \mathrm{mg}$ each of streptomycin and penicillin were added and shaken thoroughly. After the media preparation, it was allowed to cool for some minutes, after which it was poured into Petri dishes and was further allowed to solidify. $1 \mathrm{ml}$ portion of suitable dilutions of the samples were used to inoculate the Petri dishes containing PDA. The plates were incubated at $28^{\circ} \mathrm{C}$ for 2-5days and examined for the growth of fungi and the Colony Forming Unit (CFU).

$$
c f u=\frac{\text { colony counted }}{\text { inoculum volume }(\mathrm{ml}) \text { plated }} x \text { dilution factor }
$$

Treatment of sesame seeds with plant extracts of hot pepper, baobab and ordeal tree leaves

Sesame seeds were surface sterilized for 2 mins in $80 \%$ ethanol and rinsed twice in sterile distilled water. One gram of sesame seeds were placed in separate Petri dishes containing ordeal tree leaf, baobab, hot pepper that were ground into fine powder diluted with distilled water at the ratio of $2: 1(\mathrm{w} / \mathrm{v})$ for $100 \%$ concentration and ratio $1: 9(\mathrm{w} / \mathrm{v})$ for $10 \%$ concentration, where $100 \%$ is highly concentrated and $10 \%$ is diluted[16] (Satish et al.,2007). The sesame seeds which were placed into the Petri dishes containing the respective plant materials were later removed from the Petri dishes and were further preserved inside zip sachet for 2 weeks at room temperature. After the seeds preservations, it was ground into fine powder with a pestle and mortar. One gram of the ground sesame seeds which was preserved with different plant materials were introduced into $9 \mathrm{ml}$ portion (stock) of sterile water in a test tube and was shaken very well. Four fold serial dilutions were then prepared, then $1 \mathrm{ml}$ of the stock was introduced into the first test tube and shaken, then $1 \mathrm{ml}$ was transferred from the first test tube $\left(10^{-}\right.$ $\left.{ }^{1}\right)$ into the second test tube $\left(10^{-2}\right)$ and so on and finally $1 \mathrm{ml}$ was decanted from the last test tube $\left(10^{-4}\right)$. The potato dextrose agar used for the culture of fungi was prepared with an autoclave at $121^{\circ} \mathrm{C}$ for $15 \mathrm{mins}$. After the media preparation, it was allowed to cool for some mins. After which it was further poured into Petri dishes and was allowed to solidify. Approximately $1 \mathrm{ml}$ portion of suitable dilutions were used to inoculate the Petri dishes containing the culture media. The plates were incubated at $28^{\circ} \mathrm{C}$ for $2-$ 5 days and examined for the growth of molds and CFU. Experimental set up was arranged accordingly in a complete randomized design (CRD) replicated three times.

\section{Identification of fungi}

After incubation for 5 days colonies of different shapes and colours were observed on the plates and number of colonies on each plate was multiplied with the dilution factor. A pure culture of each colony type on each plate was obtained by sub-culturing each of the different colonies onto PDA plates and then incubated at room temperature. The sub-cultured colonies were fully grown as pure culture after 5 days. The identification of fungi was done using light microscope. With the aid of a flamed and cooled needle a small portion of the mycelium was picked form the edge along with its spores and placed into the drop of lactophenol-blue on a clean glass slide. Another needle was used to tease the inoculum gently and used to mix it with the stain. A cover glass was placed over the preparation and care was taken to avoid trapping of air bubbles in the stain. The identification of fungi colonies was also done macroscopically using a hand lens. The observed structures were compared with the scheme of [15] (Barnnet, 2002) for identification as stated in Table 1.

\section{Data collection and analysis}

The incidence of fungi species and their colony forming units in each of the plant extracts and in sesame seeds preserved with it were recorded after 5 days.

Data were subjected to Analysis of Variance (ANOVA) and treatment means were separated by Duncan Multiple Range Test (DMRT) at $(\mathrm{p}<0.05)$ level of probability using Genstat, $10^{\text {th }}$ Edition statistical ${ }^{\text {ee }}$ package. All the zeros were square root transformed using $\mathrm{x}+1 / 2$ so that the assumption of analysis of variance would not be violated

\section{Results and Discussion}

\section{Screening of botanical materials for fungi load}

The analysis of variance (ANOVA) showed that there was significant $(\mathrm{p} \leq 0.05)$ difference between the incidence of fungal load in the botanical materials screened in the laboratory.

The A.niger load on the cultured ordeal tree stem bark extract was significantly $(\mathrm{p}<0.05)$ higher than in all other botanical materials (Table 1).There was no A.niger observed on the hot pepper, baobab and ordeal tree leaf extracts. The Fusarium spp. load on the ordeal tree stem and ginger extract was significantly $(\mathrm{p}<0.05)$ higher than in other investigated botanical materials. There was no fungal colony observed on the baobab and ordeal tree leaf extract. A.flavus load was observed only on garlic and ordeal tree stem extracts and this was significantly $(\mathrm{p}<0.05)$ higher than in other botanical materials. The Penicillium spp. load on ginger extract was significantly $(\mathrm{p}<0.05)$ higher than in all other botanical materials. Mucor spp. was the least species of fungi observed on all the six cultured botanicals material. The only fungi species observed on hot pepper extracts was Mucor spp.(Table 1). On ginger, Fusarium spp. had the highest number of colony (14.0) and closely followed by Penicilluim spp. (12.0), while A.flavus and Mucor spp. had no colony. On hot pepper, Mucor spp. had one colony (1.0) while A.niger, A.flavus, Penicillium spp. and Fusarium spp. were absent. On garlic, A.flavus had the highest units of colony (8.0) and closely followed by A.niger while Mucor spp. had no colony unit.On ordeal tree stem extract A.niger had the highest units of colony (20.0) followed by Fusarium

\section{Volume 5 Issue 2, February 2016}




\section{International Journal of Science and Research (IJSR) \\ ISSN (Online): 2319-7064}

Index Copernicus Value (2013): 6.14 | Impact Factor (2014): 5.611

spp. (15.0) and A.flavus (8.0) while Penicillium spp. and Mucor spp. had no colony unit.

Table 1: Mycoflora screening of some botanical material marketed in Gwagwalada Abuja Nigeria

\begin{tabular}{|c|c|c|c|c|l|}
\hline Extract treatment & Aspergillus niger & Fusarium spp. & Aspergillusflavus(cfug/ml) & Penicillium spp. & Mucor spp. \\
\hline Ginger & $5.00^{\mathrm{c}}$ & $14.00^{\mathrm{a}}$ & $0.00^{\mathrm{b}}$ & $12.00^{\mathrm{a}}$ & $0.00^{\mathrm{b}}$ \\
\hline Hot pepper & $0.00^{\mathrm{d}}$ & $0.00^{\mathrm{c}}$ & $0.00^{\mathrm{b}}$ & $0.00^{\mathrm{b}}$ & $1.00^{\mathrm{a}}$ \\
\hline Garlic & $6.00^{\mathrm{c}}$ & $3.00^{\mathrm{b}}$ & $8.00^{\mathrm{a}}$ & $1.00^{\mathrm{b}}$ & $0.00^{\mathrm{b}}$ \\
\hline $\begin{array}{c}\text { Ordeal tree stem } \\
\text { bark }\end{array}$ & $20.00^{\mathrm{a}}$ & $15.00^{\mathrm{a}}$ & $8.00^{\mathrm{a}}$ & $0.00^{\mathrm{b}}$ & $0.00^{\mathrm{b}}$ \\
\hline $\begin{array}{c}\text { Ordeal tree leaf } \\
\text { extract }\end{array}$ & $0.00^{\mathrm{d}}$ & $0.00^{\mathrm{c}}$ & $0.00^{\mathrm{b}}$ & $0.00^{\mathrm{b}}$ & $0.00^{\mathrm{b}}$ \\
\hline Baobableaf & $0.00^{\mathrm{d}}$ & $0.00^{\mathrm{c}}$ & $0.00^{\mathrm{b}}$ & $0.00^{\mathrm{b}}$ & $0.00^{\mathrm{b}}$ \\
\hline Control(PDA) & $0.00^{\mathrm{d}}$ & $0.00_{\mathrm{c}}$ & $0.00^{\mathrm{b}}$ & $0.00^{\mathrm{b}}$ & $0.00^{\mathrm{b}}$ \\
\hline
\end{tabular}

Means with same alphabet are not significantly different from one another on the same column using Duncan's Multiple Range Test (DMRT) at 5\% probability level.

The analysis of variance of mycoflora screening of sesame seeds treated with selected botanical materials showed that there was significant $(\mathrm{p} \leq 0.05)$ difference due to the treatment effects. A.niger, Fusarium spp., A.flavus, Penicillium spp.,Mucor spp. and Alternariaspp. were observed to be present on the untreated sesame seeds before and after storage (Table 2). The unit of colony of A.nigeron cultured sesame seeds before storage was significantly $(\mathrm{p}<0.05)$ higher than those preserved with hot pepper at $100 \%$ and $10 \%$ level of concentration. The seeds treated with baobab and ordeal tree leaf extracts at $100 \%$ and $10 \%$ inhibited the growth of A.niger. The Fusarium spp. load on the sesame seeds before and after storage was significantly $(\mathrm{p}<0.05)$ higher than the seeds preserved with hot pepper at $100 \%$ and $10 \%$ and the ordeal tree leaf extract at $10 \%$. The A.flavus load on the untreated seeds before storage was significantly $(\mathrm{p}>0.05)$ higher than the seeds treated with hot pepper, baobab and ordeal tree leaf extract at $100 \%$ and $10 \%$.The Penicillium spp. load on sesame seeds before and after treatment with hot pepper at $100 \%$ was significantly $(\mathrm{p}<0.05)$ higher than the seeds preserved with ordeal tree leaf extract at $10 \%$. The Mucorspp. load on the seeds after storage was significant $(\mathrm{p}<0.05)$ higher but closely followed by sesame seeds only before storage and sesame seeds treated with hot pepper at $100 \%$ and $10 \%$. The Alternaria spp. load on the seeds before storage was significantly $(p>0.05)$ higher but closely followed by the seeds only after storage. On untreated sesame seed before storage A.niger had the highest unit of colonies (8.00) and closely followed by Fusarium spp. and Penicillum spp. (5.00) and A.flavus (4.00) while Mucor spp. had the least colony units. On untreated sesame seeds after storage A.niger and Fusarium spp. had the highest units of colony (5.00) and closely followed by Penicillium spp. (4.00) while A.flavus and Mucor spp. had the least units of colony (2.00). On Sesame seeds preserved with hot pepper at $10 \%$ level of concentration, A.niger had the highest units of colony (5.00) and followed by Fusarium spp. (2.00) and Mucor spp. (1.00). Those seeds preserved with hot pepper (100\%)had the highest colony units (4.00)of A.niger and Penicillum spp. and followed by Fusarium spp. (2.00) and Mucor spp. (1.00) (Table 2).On the seeds preserved with ordeal leaf extract (10\%) Fusarium and Penicillium spp. had a colony unit of one (1.00) respectively. All the six fungal species that were observed in the infected sesame seeds before and after storage were absent in sesame seeds preserved with baobab at $100 \%$ and $10 \%$. This indicated that they were the most effective in inhibiting the infection of fungi in them.

Table 2: Mycoflora screening of sesame seeds treated with antifungal botanical extractsat different concentrations

\begin{tabular}{|c|c|c|c|c|c|}
\hline $\begin{array}{c}\text { Sesame seeds treated with } \\
\text { plant extracts }\end{array}$ & Aspergillusniger & Fusariumspp. & $\begin{array}{c}\text { Aspergillusflavus } \\
\text { (cfug/ml) }\end{array}$ & $\begin{array}{c}\text { Penicillium } \\
\text { spp. }\end{array}$ & $\begin{array}{c}\text { MucorAlternaria } \\
\text { spp. spp. }\end{array}$ \\
\hline Baobab leaf extract (100\%) & & & & & \multirow{2}{*}{$0.00^{\mathrm{b}} 0.00^{\mathrm{b}}$} \\
\hline Baobab leaf extract $(10 \%)$ & $0.00^{\mathrm{c}}$ & $0.00^{\mathrm{c}}$ & $0.00^{\mathrm{c}}$ & $0.00^{\mathrm{b}}$ & $0.00^{\mathrm{b}} 0.00^{\mathrm{b}}$ \\
\hline Ordeal leaf extract(100\%) & $0.00^{\mathrm{c}}$ & $0.00^{\mathrm{c}}$ & $0.00^{\mathrm{c}}$ & $0.00^{\mathrm{b}}$ & $0.00^{\mathrm{b}} 0.00^{\mathrm{b}}$ \\
\hline Ordeal leaf extract(10\%) & $0.00^{\mathrm{c}}$ & $1.00^{\mathrm{bc}}$ & $0.00^{\mathrm{c}}$ & $0.00^{\mathrm{b}}$ & $0.00^{\mathrm{c}}$ \\
\hline Hot pepper fruit extract(100\%) & $4.00^{\mathrm{b}}$ & $2.00^{\mathrm{b}}$ & $0.00^{\mathrm{c}}$ & $4.00^{\mathrm{b}}$ & $0.00^{\mathrm{b}} 0.00^{\mathrm{b}}$ \\
\hline Hot pepper fruit extract(10\%) & $5.00^{\mathrm{b}}$ & $2.00^{\mathrm{b}}$ & $0.00^{\mathrm{c}}$ & $0.00^{\mathrm{b}}$ & $1.00^{\mathrm{ab}} 0.00^{\mathrm{b}}$ \\
\hline Untreated sesame seed before storage & $7.00^{\mathrm{a}}$ & $5.00^{\mathrm{a}}$ & $4.00^{\mathrm{a}}$ & $5.00^{\mathrm{a}}$ & $1.00^{\mathrm{a}} 2.00^{\mathrm{b}}$ \\
\hline Untreated sesame seed after storage & $5.00^{\mathrm{b}}$ & $5.00^{\mathrm{a}}$ & $2.00^{\mathrm{b}}$ & $4.00^{\mathrm{a}}$ & $2.00^{\mathrm{a}} 1.00^{\mathrm{b}}$ \\
\hline
\end{tabular}

Means with same alphabet are not significantly differently from one another on the same column using Duncan ${ }^{\text {es }}$ Multiple Range Test (DMRT) at 5\% probability

Several authors have confirmed the antifungal properties of several plant parts and phytochemicals [16]. Extracts from many plant species have been found to be active against many phytopathogenicfungi without imposing ill side effects [17]. Aspergillusniger, Fusariumspp., A. flavus and Penicillium spp. were observed in garlic in this study. [18] Ghangaonkar reported more seed-borne fungi such as $A$. niger, $\quad$ A. flavus,
Macrophominaphaseolina, Penicilliumcorymbiferum, rhizome of Garlic From ginger Fusariumspp. And Penicillium spp. were isolated. Thi observation is similar to the report of [19] Mandeel and [20] Paull and Moss that reported Aspergillus, Fusarium, Penicillium and Rhizopus spp. isolated from ginger rhizomes.

\section{Volume 5 Issue 2, February 2016}




\section{International Journal of Science and Research (IJSR) \\ ISSN (Online): 2319-7064}

Index Copernicus Value (2013): 6.14 | Impact Factor (2014): 5.611

Only Mucor spp. was observed on the hot pepper fruits. However, [21] Matthew et al., reported that hot red pepper haboured, Rhizopus spp., Colletotrichumcapsici and Goetrichumcandidium in addition to Mucorspp. In addition, [22] Karapynar, [23] Galiet al. and [24] Ito et al., reported the inhibitory effect of red pepper fruit crude extract on the growth of $A$. parasiticus and $A$. flavus. Erythrophleumsuoveolens leaf and stem extract were found to be free from most fungi load. [25] Onuorah confirmed that the presence of erythrophleguine in the E. suaveolens is responsible for the antifungal activities of the seed.

In this study, Baobab and ordeal tree leaf extracts were generally observed to be the most tolerant or resistant to fungal infection [26] Adekunle et al., reported that E. suaveolens seed oil was fungitoxic and probably have a broad spectrum antifungal activity.[27] Cowan, (1999) associated the fungitoxicity of botanicals to phytochemical compounds such as the essential oils (catechols and eugenol) in betel pepper, sulphoxide (allicin and ajoene) in garlic (Allium sativum), terpenoid in grapefruit peel, alkaloid $(6,7-$ dimethylesculetin) in Lantana camara and phenethyleesculetin alkaloid in mesquisite (Prospisjuliflora).

Apart from the plant materials investigated in this study, [28] Bankole et al., (2006)and [29] Suleiman et al., (2010) in their findings reported that Azadirachtaindica and Morindalucidaextracts inhibited the growth of A. flavus. The activity of the steam-distillate and hot-water extracts of fresh leaves of Cymbopogon, Ocimumgratissimum, Chromoleanaodorata and fruits of Xylopiaaethiopica against Utilagomaydis, Ustilagovirens, Curvularialunata, and Rhizopusspp., reducing growth by 10-60\%[30] (Awuah and Ellis, 2002); and the tomato fruit rot, which is commonly observed in local markets in many parts of Africa, can be significantly reduced with the extracts of a number of local plants such as Cassia alata, Alchorneacordifolia and Moringaoleiferaas postharvest agents[31] (Enikuomehin, 2010). On sesame seeds,[32] Ezekiel et al.(2014) isolated Alternaria, Aspergillus, Fusarium and Penicilliumspp. from sesame seeds in Plateau state Nigeria.

[33] Ojiambet al. (2000) reported the isolation of Alternariasesami in seeds obtained from Nairobi, Kenya and also [34] Gbodi et al. from Nigeria.[35] Mbah and Akueshi,[36] Afolagboye isolated A. flavus A. niger, A. nidulans, A. fumigatus, A. glaucus, Cercosporasesami, Curvularialunata and Rhizopusnigricans from the seeds in Abeokuta of the south western Nigeria. [30] Awuahand Ellis reported the effective use of packaged powders of leaves of O. grattisimum and cloves (Sizygiumaromaticum) in combination to protect groundnut kernels artificially inoculated with A. parasiticus. Similarly [37] Pundir and Jain studied the efficacy of 22 plant extracts against food associated fungi and found that ginger extract was more effective than other plant extracts.[38] Anjorinet al. reported that antifungal action of plant extracts has great potential as their fungicidal products are easy to prepare and they are safe and effective in view of being systemic in their action and easily biodegradable.

\section{Conclusion}

The results obtained from this study confirm the level of fungitoxicity of some Nigerian plant materials and indicated the effectiveness of baobab (AdansoniadigitataL.) leaves, pepper (Capsicum annum) fruit and ordeal tree (Erythrophleumsuaveolens) leaf extracts as antifungal agent on seed-borne fungi of sesame. It is imperative that further studies should determine the effect of those extracts on germination and mode of action of the extracts on the pathogenic fungi.

\section{References}

[1] A. Nasira, A. K. Shahid, A. Mushtaq, A.R. Rehana, A. Ashfag, S.M. Shanum, and M. Saquib, Seed-borne mycoflora of sesame seed and their effect on germination and seedling.Pakistan Journal of Biological Science, 7(2), pp. 243-235, 2004.

[2] M.A.H. Nasireedeen, Survey of seed borne Fungi of Sesame (SesamumindicumL.) seed in Sudan. International Journal of Educational Administration,2(2), pp.123- 130, 2006.

[3] M.M. Whalen, S.Wilson, C. Gleghorn, and B.G. Loganathan, Brief exposure of triphenyltin produces irreversible inhibition of the cytotoxic function of human natural killer cells. Environmental Research, 92(3), pp. 213-220, 2003.

[4] D.E.L. Cooke, V. Young, P.R.J.Birch, R., Toth, T.Gourlay, J.P. Day, S.F.Carne'gie, and J.M. Duncan. Phenotypic and genotypic diversity of Phytophthorainfestans populations in Scotland (199597). Plant Pathology, 52(2), pp. 181-192, 2003.

[5] P. Leroux. Mode of action of agrochemical towards plant pathogens.ComptesRendus Biologies, 326(1),pp.9-21, 2003.

[6] C.L.Wilson, A.E. Ghaouth, and W.E. Wisniewski.Prospecting in nature's store house of Biopesticides.Mexican Journal of Phytopathology, 17(1),pp.49-53, 1999.

[7] F. Castillo,D. Hernandez,G. Gallegos, R., Rodgriguez, A. Reyes, and C.N. Agurilar. In vitro antifungal activity of plant extracts obtained with alternative organic solvents against Rhizoctonasolanikuhn. Industrial crops and products, 32(3), pp. 324-328, 2010.

[8] S. R. H. Lira, G. G. F. Balvantin, C. F .D.Hernandez, A. R., Gamboa, Jasso, D. De rodriguez, and D.F. Jimenez.Evaluation of resin content and the antifungal effect of Larreatridentata(sesse and Moc.Ex.D.c).Coville extracts from two Mexican deserts against Pythium spp. Pringsh. MexicanJournal of Phytopathology, (21)2, pp. 97-101, 2003.

[9] E. Osorio, M. Flores,D. Hernandez,J. Ventura, RRodriguez, and C.N. Aguilar. Biological efficiency of polyphenolic extracts from pecan nut shell (Caryaillinoensis) pomegranate husk (Punicagranatum) and Creosote bush leaves (Larrea tridentate cov.) against plant pathogenic Fungi. Industrial Crops and Products, (31)1.pp. 153-157, 2010.

[10] C.F.D. Hernandez, R.F. Castillo, M.G. Gallegos, H.R. Rodriguez, and G.C.N. Aguilar. Lippiagraveolensand Caryaillneesisorganic extract and their in vitro effect against Rhizoctoniasolanikuhn. AmericanJournal of 


\section{International Journal of Science and Research (IJSR) \\ ISSN (Online): 2319-7064}

Index Copernicus Value (2013): 6.14 | Impact Factor (2014): 5.611

Agricultural and Biological Science, (5)3, pp. 380-384, 2010.

[11] G. Al-samarrai, H. Singh, and M. Syrahabil. Evaluating eco-friendly botanicals (natural plant extracts) as alternatives to synthetic fungicides. Annal of Agricultural.Environment Med., 19, pp. 673-676, 2012.

[12] M. Razzaghi-Abyaneh, M. Shams-Ghahfarokhi, A. Allameh, A. Kazeroon-Shiri, S. Ranjbar-Bahadori, H. Mirzahoseini, and M.B. Rezae. A survey on distribution of Aspergillus section Flavi in corn field soils in Iran: population patterns based on aflatoxins, cyclopiazonic acid and sclerotia production. Mycopathologia.(161)3, pp.183-92, 2006.

[13] V.P. Gohil, andD.G. Vala. Effect of extracts of some medicinal plants on the growth of Fusariummoniliforme. Indian J. Mycol. Plant patho., 26, pp. 110-111, 1996.

[14] U.R.T. Suthinjar, S. Satheesh, and P. Swasankar. Effect of plant product on the mycelia growth of Macrophomiaphaseolina,Proc. National seminar on IPDMSA, Annamalia University, Chidamabarm, pp. 20-21, 2003.

[15] H.L. Barnnet. Illustrated Genera of Imperfect Fungi.Minneapolis, Minn, American Journal of Sciences, U.S.A. 18(4),pp. 39-46, 2002.

[16] S. Satish, D.C. Mohana, M.P. Ranhavendra, and K.A. Raveesha. Antifungal activity of some plant extracts against important seed borne pathogens of Aspergillussp. Journal of Agricultural Technology 3(1), pp. 109-119, 2007.

[17] G.D. Lyon, T. Beglinski, and A.C. Newton. Novel disease control compounds: the potential to "immunize" plants against infection. Plant Pathology 44, pp. $407-$ 427, 1995.

[18] N.M. Ghangaonkar.Incidence of mycoflora on garlic.International Journal of Biological Science and Technology 5(1), pp. 1-3, 2013.

[19] A.Q. Mandeel. Fungal contamination of some imported spices. Mycopathologia, 159, pp. 291-298, 2005.

[20] E.R. Paull,and C.C. Chen. Pest and diseases of ginger and turmeric and their control. Pesticides, 14(11), pp. 36-40, 2008.

[21] O.K. Matthew, I.A. Ibikunle., D.A. Anibijuwon, and K.B. Shola. Antimicrobial activity of some synthetic comounds on fungi associated with post-harvest rot of red pepper (Capscium annum)Not Science and Biology. 4(4),pp. 45-48, 2012.

[22] M. Karapynar.Inhibition effects of some spice agents on Aflatoxigenicmould growths. Proceedings of the international food symposium, April 4-6 Bursa, Turkey, pp. 129-33, 1989.

[23] K.K. Gali, D.S.R. Reddy,S. Yagnika, T. Nichala, and A.S. Jacob. Exploitation of aqueous plant extracts for reduction of fungal and detoxification of aflatoxins, KMITL Science and Technology Journal, 10(2), pp.5262, 2010.

[24] H. Ito,H. Chen and J. Bunnak. Aflatoxin Production by microorganisms of the Aspergillusflavusgroup in spices and the effect of irradiation.Journal.Science of Food and Agriculture, 65, pp. 141-142, 1994.

[25] E.O. Onuorah. The wood preservative potentials of heart wood of Miliciaexcelsa and
ErythrophelumSuaveolens. Bioresource Technology, 75, pp. 171-173, 2000.

[26] A.A. Adekunle,E. Aye, and O.O. Dabiri.The composition and Antifungal properties of Erythrophleumsuaveolens.Life Science Journal, 3 (4), pp. 29-33, 2006.

[27] M.M. Cowan. Plant products as antimicrobial agents.ClinMicrobiol Rev., 12(4), pp. 564-582, 1999.

[28] S.A. Bankole, B.M. Ogunsanwo, A. Osho, and G.O. Adewuyi. Fungal contamination and Aflatoxin B1 of "egusi"melon seeds in Nigeria. Food Control, 17, pp. 814-818, 2006.

[29] M.N. Suleiman,Fungitoxic activity of Neem and Pawpaw leaves extracts onAlternariasolani, causal organism of yam rots. Advances in Environmental Biology,4(2), pp. 159-161, 2010.

[30] R.T. Awuah,and P. Ellis.Fungitoxic effects of extracts from some West African plants. Annalof Applied Biology, 115, pp. 451-453, 2002.

[31] O.A. Enikuomehin, and E. O. Oyedeji. Fungitoxic effects of some plant extracts against tomato fruit rot pathogens. Archives of Phytopathology and Plant Protection, 43(3), pp. 233-240,2010.

[32] C.N. Ezekiel,I.E. Udom,J.S. Frisvad,M.C. Adetunji, S.O. Houbraken,R.A. Samson, O.O. Atanda,M.C. Agiotto, and O.A. Onashile.Assessment of aflatoxigenicAspergillus and other fungi in millet and sesame from Plateau state Nigeria.Myxcology, 5(1), pp. 16-22, 2014.

[33] P.S. Ojiamba,R.B Narla,P.O. Ayaaecho, and J.O Nyaburd. Effect of infection level of Sesame (SesamumindicumL) Seed by Alternariasesame causingAlternarialeaf spot. Tropical Agricultural Research and Extension, 1(2), pp.125-130, 2000.

[34] T.A. Gbodi, N. Nwude,Y.O Aliu, and C.O. Kediobi. The mycoflora and some mycotoxins found in acha(DigitariaexilisTapf) in Plateau state, Nigeria. Food Chem Toxical., 24: 339-342, 1986.

[35] M.C. Mbah, and C.O. Akueshi. Effect of seed borne of Aspergillusflavus and Aspergillusnigeron germinability of sesame seed. Nig J.Hort Soc., 4, pp. 57-64, 2000.

[36] F.M. Afolagboye. Seed borne fungi of sesame (SesamumindicumL.) and their control with plant extracts, 5(1), pp. 44-48, 2011.

[37] R.K. Pundir,and P. Jain. Antifungal activity of twenty two ethanolic plant extracts against food-associated fungi.Journal of Pharmacy Research, 3, pp. 506-510, 2010.

[38] S.T. Anjorin, E. A. Salako and H.A. Makun.Control of Toxigenic Fungi and Mycotoxins withPhytochemicals: Potentials and Challenges. In:Mycotoxin and Food Safety in Developing Countries. Anthony Makun Eds. Intech publishers, pp. 181-202, 2013.

\section{Authors Profile}

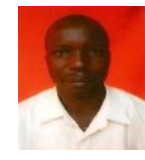

Anjorin Toba Samuel obtained a B. Agric. (Plant Science) degree from Obafemi Awolowo University, Ile -Ife, Nigeria in 1992 and M. Tech. degree in Crop Protection from Federal University of Technology, Minna in 1998. In 2005, he started his lecturing career in the Department of Crop Production, Federal University of Technology, Minna. In 2008, he obtained his $\mathrm{PhD}$ in Plant Pathology. In the same year, he resumed lecturing in the Department 


\section{International Journal of Science and Research (IJSR) \\ ISSN (Online): 2319-7064}

Index Copernicus Value (2013): 6.14 | Impact Factor (2014): 5.611

of Crop Science, University of Abuja, Abuja where he is currently a Senior Lecturer. His current areas of research focus are Crop Protection and Mycotoxicology on which he has up to 50 learned publications.

Salako Ezekiel Adebayo obtained aB.Sc degree from University of Ife(now Obfemi awolowo University) IleIfe in 1972, and $\mathrm{PhD}$ fromthe University of Arkansas, USA in 1978. He has since 1979, been teaching Crop Protection and related courses at both undergraduate and postgraduate levels, first at the Ahmadu Bello University, Zaria (1979 - 1987), then at Federal University of Technology, Minna (1987- 2006) and in Unversity of Abuja, Abuja 2006 till date. The Professor of Plant Pathology is the the pioneer Dean of Faculty of Agriculture, at both Federal University of Technology, Minna and University of Abuja, Abuja, Nigeria

Oluchi Nwogbo obtained her B. Agric (Crop Science) from the Faculty of Agriculture, University of Abuja in 2015. He worked extensively on seed-borne fungi of sesame(Sesemum indicum). She is currently on her National Youth Service Corps in Niger State of Nigeria 